\title{
FACTORS ASSOCIATED WITH PERCEIVED SOCIAL SUPPORT IN OLDER PEOPLE WITH CANCER
}

\section{Fatores associados ao apoio social percebido pelo idoso com câncer}

\author{
Tábatta Renata Pereira de Brito ${ }^{a}$ (), Giovana de Souza Gomes Penido ${ }^{\text {(D), }}$

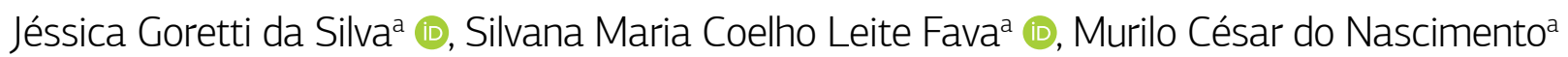

OBJECTIVE: To analyze factors associated with perceived social support in older people with cancer. METHODS: This was a cross-sectional, analytical study conducted with a convenience sample of 134 older people seen at a specialist cancer treatment unit in a hospital located in a municipal district in the South of Minas Gerais state, Brazil. Data collection was conducted by interview and analysis of medical records. Social support was analyzed using the Medical Outcomes Study social support scale. The Mann-Whitney and Kruskal-Wallis tests were used to analyze differences between means. Linear regression was used for analysis of associations. RESULTS: The majority of the sample of older people with cancer analyzed were male, aged from 60 to 74 years, and reported high mean scores for material support; affective support; positive social interaction; and emotional/ informational support. Factors with positive associations with social support were: not living alone; income one to three times the minimum wage; having a partner; rating health as good/very good; and presence of comorbidity. Factors with negative associations were: poor/very poor perceived income and polypharmacy use. CONCLUSIONS: This sample of older people reported high mean scores for material support; affective support; positive social interaction; and emotional/informational support. Factors associated with perceived social support were: living arrangements; family income; perceived sufficiency of income; marital status; health self-assessment; comorbidity; and polypharmacy.

KEYWORDS: older people; neoplasms; social support.

OBJETIVO: Analisar os fatores associados ao apoio social percebido pelo idoso com câncer. METODOLOGIA: Trata-se de um estudo seccional analítico realizado com uma amostra por acessibilidade de 134 idosos atendidos num hospital de referência para tratamento oncológico localizado em um município da Região Sul do estado de Minas Gerais. A coleta de dados foi feita por meio de entrevista e análise de prontuário. Para a avaliação do apoio social, utilizou-se a escala de apoio social do Medical Outcomes Study. Utilizaram-se os testes de Mann-Whitney e Kruskal-Wallis para análise de diferença de médias. A análise de associação foi feita por meio de regressão linear. RESULTADOS: A maior parte dos idosos com câncer avaliados era do sexo masculino, com idade entre 60 e 74 anos e referiram elevados escores médios de apoio material, afetivo, interação social positiva e apoio emocional/informação. Os fatores associados positivamente ao apoio social foram: não morar sozinho, renda de um a três salários mínimos, possuir companheiro, avaliar a saúde como boa/muito boa e presença de comorbidade. Já os fatores associados negativamente foram: percepção de renda muito ruim/ruim e uso de polifarmácia. CONCLUSÕES: Os idosos referiram elevados escores médios de apoio material, afetivo, interação social positiva e apoio emocional/informação. Os fatores associados à percepção de apoio social foram: arranjo domiciliar, renda familiar e percepção de suficiência de renda, situação conjugal, autoavaliação de saúde, comorbidade e polifarmácia.

PALAVRAS-CHAVE: idoso; neoplasias; apoio social.

a Universidade Federal de Alfenas - Alfenas (MG), Brazil.

Correspondence data

Tábatta Renata Pereira de Brito - Rua Gabriel Monteiro da Silva, 976 - Centro - CEP: 37130-001 - Alfenas (MG), Brasil. E-mail: tabatta_renata@hotmail.com Received on: 08/21/2020. Accepted on: 10/23/2020

How to cite this article: Brito TRP, Penido GSG, Silva JG, Fava SMCL, Nascimento MC. Factors associated with perceived social support in older people with cancer. Geriatr Gerontol Aging. 2021;15:e0210004. https://doi.org/10.5327/Z2447-212320212000104

https://doi.org/10.5327/Z2447-212320212000104 


\section{INTRODUCTION}

Cancer is the second-ranked cause of death among women and men aged 60 years or over and more than $70 \%$ of cancer-related deaths in Brazil occur in people within this age range. ${ }^{1}$ These epidemiological data can be explained by the fact that older people are more likely to develop cancer than younger people, which, combined with aging of the population and increased life expectancy, makes cancer in older people an increasingly common problem. ${ }^{2}$

Analyzing the specific needs of older people with cancer, it is found that the physiological changes that occur with aging create a need to set out a care plan that takes them into consideration, but that also takes into consideration the psychosocial aspects related to them. ${ }^{3}$ In this context, social support is an important resource that health professionals should make use of. ${ }^{4}$

Social support can be understood as the social resources that people perceive as available or which are actually provided to them in the context of informal support groups and informal help relationships. It is defined as perceived support when what is under consideration is the individual's beliefs with relation to the availability of a range of types of help provided by the social network, and is known as received support when that help is effectively forthcoming. ${ }^{5}$ In the specific case of older people with cancer, social support exchange is a crucial activity in coping with the disease, since diagnosis and treatment cause physical and emotional stress. ${ }^{6}$

It is known that social support can contribute to many aspects of cancer treatment, including management of symptoms and coordination of care and treatment with basic and instrumental activities of daily living. ${ }^{4}$ Moreover, social support exchanges provide opportunities for sharing emotions and feelings with relatives, friends, or groups, promoting affective alliances that have positive effects. These effects are due to the fact that individuals who feel loved and supported have lower levels of anxiety, depression, and somatic diseases, which are related to reduced negative effects of cancer on the body. ${ }^{7}$

Within this context, considering the importance of social support for coping with cancer and the paucity of studies on this subject in Brazil, the objective of this study was to analyze factors associated with perceived social support in older people with cancer.

\section{METHODS}

This is a quantitative, cross-sectional, analytical study conducted at a general hospital in a municipal district in the South of the state of Minas Gerais, in Brazil. The hospital is a not-for-profit philanthropic organization that has an oncology unit that is a cancer treatment referral center.

Sample selection was non-probabilistic, by convenience. A sample was recruited comprising 134 people who met the following inclusion criteria: age greater than or equal to 60 years, confirmed diagnosis of cancer either in treatment or follow-up, and cognitive status sufficient to answer the questionnaires (as perceived by the interviewer during presentation of the study and when inviting the patient to participate).

Data collection was conducted from March to December of 2019 in interviews and by analysis of medical records. Interviews were conducted by undergraduate and postgraduate students after training by the researchers, were held in medical consulting rooms in the hospital that was the research setting attention, and lasted a mean duration of 30 minutes. Data were compiled using the Google Forms online platform. Data on cancer diagnoses and treatments were collected by analysis of medical records.

The study was granted institutional authorization by the Hospital de Referência em Oncologia do Município and was approved by the Research Ethics Committee at the Universidade Federal de Alfenas (UNIFAL), under decision number 2.816.020 and protocol CAAE 94986418.4.0000.5142. The objectives, risks, benefits, contributions, and ethical aspects of the study were explained to participants. They were then given a free and informed consent form to read and any doubts they had about it were answered. After signature of the free and informed consent form, the data collection instrument was administered.

The dependent study variables were: material support; affective support; positive social interaction; and emotional/ informational support. These variables were collected during the interview using the Medical Outcomes Study (MOS) social support scale. This is a scale that was originally created for the MOS, which was a study that recruited 2987 adults who used health services in Boston, Chicago, and Los Angeles, in the United States, and had one or more of the following chronic diseases: hypertension; diabetes; coronary disease; or depression. ${ }^{8}$ The scale has been translated into Portuguese and validated in Brazil. ${ }^{9}$ The questionnaire comprises 19 items, covering five functional dimensions of social support (material; affective; emotional; positive social interaction; and informational); but following an a posteriori classification proposal, the emotional and informational dimensions were collapsed into a single dimension. ${ }^{10}$ For each item, respondents were requested to indicate the frequency with which they considered each type of support to be available: never ( 0 points); rarely (1 point); sometimes ( 2 points); almost always (3 points); or always (4 points). Depending on 
the responses chosen, a final score is calculated for each of the dimensions, varying from 15 to 100 points, where the higher the score the higher the level of social support. ${ }^{9}$

The data from the MOS social support scale were analyzed numerically (scores from 15 to 100 points) ${ }^{9}$ and categorically, ${ }^{10}$ using the scores to classify dimensions as follows: emotional/informational support - low ( 0 to 12 points), medium (13 to 28 points), or high (29 to 32 points); positive social interaction - low ( 0 to 6 points), medium ( 7 to 13 points), or high (14 to 16 points); material support low (0 to 6 points), medium (7 to 13 points), or high (14 to 16 points); and affective support - low (0 to 4 points), medium (5 to 10 points), or high (11 to 12 points). ${ }^{10}$

The independent study variables were: sex (female; male); age group (60 to 74 years; 75 years or over); marital status (no partner; has partner);, educational level (illiterate; primary education; secondary or higher education); religion (Catholic; Evangelic; others); living arrangements (lives alone - yes; no); monthly family income ( $\leq 1$ multiples of minimum wage; > $1 \leq 3$ multiples of minimum wage; > 3 multiples of minimum wage); perceived sufficiency of income (very good/ good; regular; poor/very poor); presence of carer (yes; no); comorbidity (no; yes), polypharmacy (takes 5 or more medications — no; yes); health self-assessment (poor/very poor; regular; good/very good); and care needs (satisfied; low need). Additionally, the following variables obtained by analysis of medical records were also considered independent study variables: time since diagnosis ( $\leq 1$ year; $>1$ year); metastasis (no; yes); radiotherapy administered (no; yes); chemotherapy administered (no; yes); and surgery administered (no; yes).

The variable 'care needs' was measured using the Supportive Care Needs Survey - Short Form 34 (SCNS-SF 34). This is a 34 -item scale in which each item comprises a question with the following response options: "No need, not applicable" (1); "No need, satisfied" (2); "Low need" (3); "Moderate need" (4) or "High need" (5). ${ }^{11}$ The instrument was developed in Australia and has been validated in Brazil. ${ }^{12}$ In this study, respondents only endorsed the options "No need, satisfied" or "Low need", and so the results were classified into two categories.

Data were input to Microsoft Excel ${ }^{\oplus}$ and analyzed using Stata version 15.0. A descriptive analysis of the data was conducted, estimating frequency distributions, means, and standard deviations for the continuous study variables. Proportions were estimated for the categorical variables. The Kolmogorov-Smirnov test was used to check normality of variables. Considering distributions nonparametric, the Mann-Whitney and Kruskal-Wallis tests were used to analyze differences between means. Analysis of associations was performed by linear regression, since analysis of the residuals indicated normal distribution. A 5\% significance level was adopted.

\section{RESULTS}

Of the 134 older people assessed, there were higher percentages of men (55.22\%); individuals in the age group from 60 to 74 years (76.87\%); people who reported that they did have a partner (64.93\%); and people who lived with at least one other person in the household (88.06\%). Majorities of the participants had primary education (71.74\%); reported being Catholics (79.85\%); reported a family income in the range of one to three times the minimum wage (84.33\%); and stated that their financial status was regular to very poor to meet their personal and family needs (55.22\%).

With regard to general health characteristics, $52.24 \%$ had other comorbidities in conjunction with cancer; $10.45 \%$ used polypharmacy; and $54.48 \%$ assessed their current health as very good/good. With regard to the characteristics of their cancer, the majority of these older people had been diagnosed more than 1 year previously (60.47\%); had already undergone surgery for cancer (87.60\%); had had or were on chemotherapy (72.09\%); were satisfied that their care needs related to the disease were met (81.34\%); and did not have a carer (85.07\%). It was observed that $41.09 \%$ had not manifested metastasis and $17.05 \%$ had undergone or were currently in treatment with radiotherapy. It should, however, be pointed out that there were high percentages of missing responses to the last two items.

With regard to perceived social support, the mean scores observed were 95.33 for material support $(\mathrm{SD}=11.89$ ); 93.40 for affective support $(\mathrm{SD}=18.65)$; 88.57 for positive social interaction ( $\mathrm{SD}=23.16$ ); and 88.01 for emotional/ informational support ( $\mathrm{SD}=21.51)$. Analyzing dimensions by category (low, medium, or high), the majority of the older people perceived their received social support as high in all dimensions.

The mean score for material support was significantly lower among older people who did not have a partner; who lived alone; who reported a monthly income less than or equal to one multiple of the minimum wage; and who considered their financial status to be poor/very poor to meet their needs. Mean scores for affective support were lower among women; those who did not have a partner; who lived alone; who reported a monthly income less than or equal to one multiple of the minimum wage; and who considered their financial status to be poor/very poor to meet their needs. Mean scores for positive social interaction were 
lower among those who did not have a partner; who lived alone; and who reported a monthly income less than or equal to one multiple of the minimum wage. Finally, lower mean scores for the dimension emotional/information were observed for those who did not have a partner and those who lived alone (Table 1).
Analyzing the differences in mean scores for dimensions of social support in relation to general characteristics of health and specific characteristics of cancer, there were only statistically significant differences in scores for affective support; positive social interaction; and emotional/information support. Lower scores for affective support were observed

Table 1. Distribution of the sample of older people by mean scores for perceived social support and socioeconomic characteristics. Alfenas, Brazil, 2019 ( $n=134)$.

\begin{tabular}{|c|c|c|c|c|c|c|c|c|}
\hline Variable & $\begin{array}{l}\text { Material } \\
\text { support } \\
\text { Mean (SD) }\end{array}$ & p-value & $\begin{array}{l}\text { Affective } \\
\text { support } \\
\text { Mean (SD) }\end{array}$ & $\mathrm{p}$-value & $\begin{array}{l}\text { Positive } \\
\text { social } \\
\text { interaction } \\
\text { Mean (SD) }\end{array}$ & p-value & $\begin{array}{c}\text { Emotional/ } \\
\text { Informational } \\
\text { support } \\
\text { Mean (SD) }\end{array}$ & p-value \\
\hline \multicolumn{9}{|l|}{ Sex ${ }^{a}$} \\
\hline Female & $93.43(14.42)$ & \multirow{2}{*}{0.17} & $90.83(20.14)$ & \multirow{2}{*}{0.04} & 85.31 (26.62) & \multirow{2}{*}{0.30} & $84.68(23.32)$ & \multirow{2}{*}{0.05} \\
\hline Male & $96.87(9.13)$ & & $95.49(17.11)$ & & 91.21 (19.63) & & 90.70 (19.65) & \\
\hline \multicolumn{9}{|l|}{ Age group ${ }^{a}$} \\
\hline 60 to 74 years & $94.90(12.34)$ & \multirow{2}{*}{0.35} & $92.96(18.73)$ & \multirow{2}{*}{0.25} & $86.71(24.83)$ & \multirow{2}{*}{0.05} & $86.19(22.91)$ & \multirow{2}{*}{0.15} \\
\hline 75 years or over & $96.77(10.32)$ & & $94.89(18.41)$ & & $94.75(15.12)$ & & 94.05 (14.72) & \\
\hline \multicolumn{9}{|l|}{ Marital status ${ }^{a}$} \\
\hline No partner & $92.55(14.11)$ & \multirow{2}{*}{0.01} & $87.41(26.15)$ & \multirow{2}{*}{0.01} & $80.05(30.24)$ & \multirow{2}{*}{0.01} & 79.98 (26.91) & \multirow{2}{*}{0.01} \\
\hline Has partner & $96.83(10.21)$ & & $96.64(11.83)$ & & $93.17(16.62)$ & & $92.34(16.54)$ & \\
\hline \multicolumn{9}{|l|}{ Educational level $^{\mathrm{b}}$} \\
\hline Illiterate & $100(0)$ & \multirow{3}{*}{0.13} & $94.64(17.72)$ & \multirow{3}{*}{0.94} & 91.96 (17.23) & \multirow{3}{*}{0.74} & $93.08(14.71)$ & \multirow{3}{*}{0.52} \\
\hline Primary education & 94.14 (13.53) & & $93.66(17.62)$ & & $89.77(21.14)$ & & 88.89 (19.74) & \\
\hline $\begin{array}{l}\text { Secondary or } \\
\text { higher education }\end{array}$ & 97.39 (6.34) & & $91.66(23.14)$ & & 81.77 (31.91) & & $81.51(29.52)$ & \\
\hline \multicolumn{9}{|l|}{ Religion ${ }^{\mathrm{b}}$} \\
\hline Catholic & $95.21(12.32)$ & \multirow{3}{*}{0.92} & $93.22(18.42)$ & \multirow{3}{*}{0.81} & $90.12(22.02)$ & \multirow{3}{*}{0.06} & 89.16 (19.91) & \multirow{3}{*}{0.53} \\
\hline Evangelical & $95.00(11.21)$ & & $97.91(5.93)$ & & $85.00(23.65)$ & & $87.03(21.82)$ & \\
\hline Others & $98.21(4.74)$ & & $83.33(37.25)$ & & $75.00(35.52)$ & & $73.21(37.81)$ & \\
\hline \multicolumn{9}{|l|}{ Living alone ${ }^{a}$} \\
\hline Yes & 87.89 (18.03) & \multirow{2}{*}{0.01} & $88.54(17.91)$ & \multirow{2}{*}{0.02} & $78.90(28.62)$ & \multirow{2}{*}{0.01} & $77.34(23.55)$ & \multirow{2}{*}{0.01} \\
\hline No & $96.34(10.52)$ & & $94.06(18.72)$ & & $89.88(22.13)$ & & $89.45(22.13)$ & \\
\hline Monthly income ${ }^{b}$ & & & & & & & & \\
\hline $\begin{array}{l}\leq 1 \text { multiple of } \\
\text { minimum wage }\end{array}$ & $84.61(20.13)$ & & $83.33(25.45)$ & & $75.48(31.82)$ & & 72.59 (30.44) & \\
\hline $\begin{array}{l}>1 \leq 3 \text { multiples } \\
\text { of minimum wage }\end{array}$ & $96.23(10.44)$ & 0.01 & 94.10 (18.14) & 0.01 & $89.26(22.34)$ & 0.01 & $89.54(20.01)$ & 0.05 \\
\hline $\begin{array}{l}>3 \text { multiples of } \\
\text { minimum wage }\end{array}$ & $100(0)$ & & $100(0)$ & & $100(0)$ & & $91.40(16.23)$ & \\
\hline Perceived sufficiency & f income ${ }^{b}$ & & & & & & & \\
\hline Very good/good & $95.62(11.81)$ & & $96.52(11.82)$ & & $89.58(21.11)$ & & $87.23(21.63)$ & \\
\hline Regular & $97.09(8.25)$ & 0.01 & $94.10(17.91)$ & 0.01 & 91.27 (19.42) & 0.23 & $92.67(14.42)$ & 0.12 \\
\hline Poor/very poor & 87.89 (19.23) & & $79.16(32.43)$ & & $75.00(36.55)$ & & $74.02(34.24)$ & \\
\hline
\end{tabular}

SD: standard deviation; ${ }^{\mathrm{a}}$ Mann-Whitney test; ${ }^{\circ} \mathrm{Kruskal-Wallis} \mathrm{test.}$ 
among older people who used polypharmacy; lower scores for positive social interaction were found among those who self-assessed their health as poor/very poor; and lower scores for emotional/informational support were seen among those who did not report comorbidities and who assessed their current health as poor/very poor (Table 2).

Table 2. Distribution of the sample of older people by mean scores for perceived social support and general health characteristics and specific characteristics of cancer. Alfenas, Brazil, 2019 ( $n=134)$.

\begin{tabular}{|c|c|c|c|c|c|c|c|c|}
\hline Variable & $\begin{array}{l}\text { Material } \\
\text { support } \\
\text { Mean (SD) }\end{array}$ & p-value & $\begin{array}{l}\text { Affective } \\
\text { support } \\
\text { Mean (SD) }\end{array}$ & p-value & $\begin{array}{c}\text { Positive } \\
\text { social } \\
\text { interaction } \\
\text { Mean (SD) }\end{array}$ & p-value & $\begin{array}{l}\text { Emotional/ } \\
\text { Informational } \\
\text { support } \\
\text { Mean (SD) }\end{array}$ & p-value \\
\hline \multicolumn{9}{|l|}{ 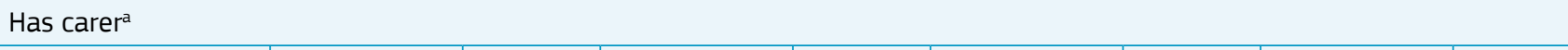 } \\
\hline Yes & $99.68(1.31)$ & \multirow{2}{*}{0.07} & $98.33(5.74)$ & \multirow{2}{*}{0.27} & 88.43 (19.44) & \multirow{2}{*}{0.39} & $88.43(20.12)$ & \multirow{2}{*}{0.81} \\
\hline No & $94.57(12.72)$ & & 92.54 (19.92) & & $88.59(23.83)$ & & $87.93(21.83)$ & \\
\hline \multicolumn{9}{|c|}{ Time since diagnosis ${ }^{a}$} \\
\hline$\leq 1$ year & $93.50(14.15)$ & \multirow{2}{*}{0.29} & $93.95(16.51)$ & \multirow{2}{*}{0.68} & $90.80(20.00)$ & \multirow{2}{*}{0.68} & $88.29(20.84)$ & \multirow{2}{*}{0.43} \\
\hline$>1$ year & $96.23(10.44)$ & & $93.91(17.43)$ & & $87.58(23.82)$ & & $88.34(20.45)$ & \\
\hline \multicolumn{9}{|l|}{ Metastasis $^{\mathrm{b}}$} \\
\hline No & $97.52(7.01)$ & \multirow{3}{*}{0.26} & 95.75 (11.93) & \multirow{3}{*}{0.77} & $90.91(15.81)$ & \multirow{3}{*}{0.31} & $89.03(18.41)$ & \multirow{3}{*}{0.09} \\
\hline Yes & $93.95(13.72)$ & & $91.94(22.12)$ & & $82.70(29.92)$ & & $81.56(26.93)$ & \\
\hline $\begin{array}{l}\text { Information } \\
\text { missing }\end{array}$ & $93.20(14.94)$ & & $93.11(18.45)$ & & $90.48(22.84)$ & & 91.91 (16.95) & \\
\hline \multicolumn{9}{|l|}{ Radiotherapy ${ }^{b}$} \\
\hline No & 96.72 (9.13) & \multirow{3}{*}{0.33} & $96.42(8.13)$ & \multirow{3}{*}{0.84} & $85.71(26.81)$ & \multirow{3}{*}{0.40} & $84.37(25.42)$ & \multirow{3}{*}{0.74} \\
\hline Yes & $93.75(12.02)$ & & $94.69(11.32)$ & & $88.63(19.64)$ & & $86.93(21.93)$ & \\
\hline $\begin{array}{l}\text { Information } \\
\text { missing }\end{array}$ & $95.13(12.71)$ & & $93.12(19.74)$ & & $89.68(22.05)$ & & $89.64(18.81)$ & \\
\hline \multicolumn{9}{|l|}{ Chemotherapy $^{a}$} \\
\hline No & $96.70(12.03)$ & \multirow{2}{*}{0.06} & $94.44(16.01)$ & \multirow{2}{*}{0.53} & $92.18(16.13)$ & \multirow{2}{*}{0.40} & $90.45(18.73)$ & \multirow{2}{*}{0.28} \\
\hline Yes & $94.55(12.02)$ & & $93.72(17.54)$ & & $87.56(24.32)$ & & $87.50(21.24)$ & \\
\hline \multicolumn{9}{|l|}{ Surgery ${ }^{a}$} \\
\hline No & 94.14 (11.05) & \multirow{2}{*}{0.25} & 91.66 (18.00) & \multirow{2}{*}{0.41} & $87.10(21.32)$ & ר? & 83.78 (19.81) & 10 \\
\hline Yes & $95.29(12.22)$ & & 94.24 (17.02) & & $89.10(22.55)$ & 0.02 & $88.96(20.64)$ & 0.13 \\
\hline Comorbidity $^{a}$ & & & & & & & & \\
\hline No & 96.77 (8.14) & זمח & 94.27 (16.51) & O 81 & $84.76(26.34)$ & תח & $83.05(25.42)$ & בחת \\
\hline Yes & $94.01(14.44)$ & 0.03 & $92.61(20.42)$ & 0.01 & $92.05(20.42)$ & 0.05 & $92.54(16.13)$ & د.U \\
\hline Polypharmacy ${ }^{a}$ & & & & & & & & \\
\hline No & $95.67(11.32)$ & O & 94.37 (17.64) & O & 88.95 (23.05) & 0 & $88.67(20.72)$ & 047 \\
\hline Yes & $92.41(15.91)$ & 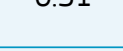 & $85.11(25.12)$ & 0.01 & $85.26(24.73)$ & 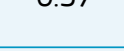 & $82.36(27.63)$ & ו ו \\
\hline Self-assessed healt & tatus & & & & & & & \\
\hline Poor/very poor & $94.23(11.23)$ & & $82.05(32.41)$ & & 69.71 (36.43) & & 69.71 (32.20) & \\
\hline Regular & $94.66(13.24)$ & 0.43 & $92.53(22.02)$ & 0.27 & $88.67(22.51)$ & 0.01 & $85.54(23.12)$ & 0.01 \\
\hline Good/very good & 95.97 (11.15) & & $96.00(10.85)$ & & 91.86 (19.01) & & $92.89(15.62)$ & \\
\hline Care needs ${ }^{\mathrm{a}}$ & & & & & & & & \\
\hline Satisfied & $95.67(14.54)$ & 0 & 93.50 (18.90) & 0 & $88.64(23.32)$ & 0 & $89.01(20.31)$ & 033 \\
\hline Low need & $95.87(11.12)$ & 0.0 & $93.00(14.54)$ & 0.7 & $88.25(22.71)$ & . & $83.62(25.82)$ & ל כ. \\
\hline
\end{tabular}

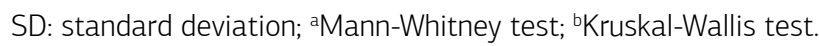


Table 3 lists factors associated with the dimensions of perceived social support. Not living alone and having an income one to three times the minimum wage were positively associated with material support. Having a partner was positively associated with affective support, whereas poor/very poor perceived sufficiency of income and polypharmacy use were negatively associated with this type of support. The only factor associated with positive social interaction was health self-assessment, and rating health as good/very good was positively associated with positive social interaction. In relation to emotional/informational support, presence of comorbidities and health self-assessment rated as good/very good were positively associated with emotional/informational support, whereas polypharmacy use was negatively associated with this type of support (Table 3).

\section{DISCUSSION}

This study analyzed factors associated with perceived social support in older people with cancer, observing positive

Table 3. Factors associated perceived social support in older people with cancer. Alfenas, Brazil 2019 ( $n=134)$.

\begin{tabular}{|c|c|c|c|c|}
\hline Variable & $\begin{array}{c}\text { Material support } \\
\beta \text { (Value } p \text { ) }\end{array}$ & $\begin{array}{l}\text { Affective support } \\
\quad \beta \text { (Value } p)\end{array}$ & $\begin{array}{c}\text { Positive social } \\
\text { interaction }^{c} \\
\beta \text { (Value } p)\end{array}$ & $\begin{array}{l}\text { Emotional/ } \\
\text { Informational } \\
\text { support }^{\mathrm{d}} \\
\beta \text { (Value } \mathrm{p} \text { ) }\end{array}$ \\
\hline \multicolumn{5}{|l|}{ Sex } \\
\hline Female & Ref. & Ref. & Ref. & Ref. \\
\hline Male & $1.91(0.35)$ & $2.44(0.44)$ & $5.18(0.19)$ & $5.11(0.13)$ \\
\hline \multicolumn{5}{|l|}{ Marital status } \\
\hline No partner & Ref. & Ref. & Ref. & Ref. \\
\hline Has partner & $1.45(0.55)$ & $8.36(0.03)^{*}$ & $7.17(0.13)$ & $5.47(0.19)$ \\
\hline \multicolumn{5}{|l|}{ Living alone } \\
\hline Yes & Ref. & Ref. & Ref. & Ref. \\
\hline No & $7.12(0.04)^{*}$ & $-0.40(0.94)$ & $4.42(0.51)$ & $8.09(0.17)$ \\
\hline \multicolumn{5}{|l|}{ Monthly income } \\
\hline$\leq 1$ multiple of minimum wage & Ref. & Ref. & Ref. & Ref. \\
\hline$>1 \leq 3$ multiples of minimum wage & $7.58(0.03)^{*}$ & $3.09(0.57)$ & $6.57(0.33)$ & $9.42(0.11)$ \\
\hline$>3$ multiples of minimum wage & $10.36(0.05)$ & 7.09 (0.39) & $15.36(0.13)$ & $8.98(0.31)$ \\
\hline
\end{tabular}

\begin{tabular}{l|c|c|c|c}
\hline Very good/good & Ref. & Ref. & Ref. & Ref. \\
\hline Regular & $1.72(0.41)$ & $-1.80(0.58)$ & $1.04(0.79)$ & $4.48(0.20)$ \\
\hline Poor/very poor & $-5.32(0.12)$ & $-14.91(0.01)^{*}$ & $-9.35(0.16)$ & $-8.56(0.14)$ \\
\hline Comorbidity &
\end{tabular}

\begin{tabular}{l|c|c|c|c}
\hline No & Ref. & Ref. & Ref. & Ref. \\
\hline Yes & $-1.93(0.35)$ & $-0.54(0.86)$ & $7.88(0.05)$ & $10.90(0.01)^{*}$ \\
\hline
\end{tabular}

Polypharmacy

\begin{tabular}{|c|c|c|c|c|}
\hline No & Ref. & Ref. & Ref. & Ref. \\
\hline Yes & $-4.82(0.15)$ & $-12.00(0.02)^{*}$ & $-7.84(0.22)$ & $-10.44(0.06)^{*}$ \\
\hline \multicolumn{5}{|c|}{ Self-assessed health status } \\
\hline Poor/very poor & Ref. & Ref. & Ref. & Ref. \\
\hline Regular & $-2.07(0.57)$ & $5.27(0.35)$ & $13.26(0.06)$ & $9.53(0.12)$ \\
\hline Good/very good & $-1.22(0.73)$ & 7.21 (0.19) & $16.93(0.01)^{*}$ & $17.71(0.01)^{*}$ \\
\hline
\end{tabular}

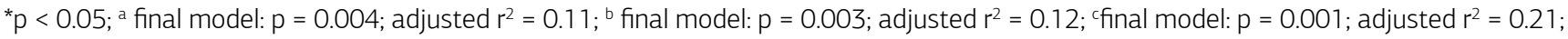
dfinal model: $p=0.000$; adjusted $r^{2}=0.24$; Ref.: reference. 
associations with not living alone; income of one to three times the minimum wage; having a partner; rating health as good/very good; and presence of comorbidities. Factors with negative associated were poor/very poor perceived sufficiency of income and polypharmacy use.

With regard to the characteristics of the older people assessed, the results are similar to those of other studies. The higher proportion of men is linked to the higher prevalence of cancer in men, whether because of greater survival among women, or because of the more fatal types of cancer that emerge among the male population. ${ }^{13-15}$

Low educational level and worst rating of sufficiency of income were also identified in a study about the incidence of cancer in Brazil as factors associated with greater exposure to risk factors and restricted access to health services. Additionally, the prevalence among the older people assessed of the categories family income from one to three multiples of the minimum wage and perceived sufficiency of income ratings from regular to very poor is indicative of these people's situation of scarcity of financial resources, which is compounded by the expenditure inherent to the process of a family member sickening due to cancer. Despite the existence of the Brazilian National Health System (SUS Sistema Único de Saúde), which is free and universal in Brazil, the individual cost burden of the disease is still high because of additional costs linked to diagnosis and treatment, contributing to the greater need for material support among these older people. ${ }^{16}$

With relation to mean social support scores in the dimensions assessed, the results were similar to the findings of another Brazilian study, conducted with 268 cancer patients in treatment. As in the present study, the authors of that study used the social support scale from the MOS and the results revealed high scores for all types of support, with higher mean scores for material support and affective support and lower scores for positive social interaction, emotional support, and informational support. ${ }^{17}$ Although it used a different scale to assess social support, a study conducted in Turkey with 6754 individuals with cancer also observed high social support scores, providing further evidence that people with cancer report high perceived social support. ${ }^{18}$

The families of people with cancer generally report financial difficulties over the course of the disease and sometimes the financial difficulty preexists the diagnosis of cancer, worsening as the disease progresses because of extra expenditure on transport, nutritional supplements, medications, dressings and/or personal hygiene products, and even rental of medical and care equipment. ${ }^{17,19}$ These demands may explain offers of material support from relatives, friends, and close people, which might be the basis for the high scores for material support reported by the older people assessed.

While still high, the mean score for emotional/informational support was the lowest of the domains, revealing a need to stimulate exchanges of these types of support. Information is fundamental for patients' decision-making, in addition to contributing to self-management of the disease. ${ }^{6,17,19}$ In turn, emotional support can help with overcoming the impact of a cancer diagnosis and contribute to improve understanding of emotions and feelings that emerge over the course of the disease. ${ }^{19}$

With regard to factors associated with social support, not living alone; having an income one to three times the minimum wage; having a partner; rating health as good/very good; and reporting comorbidities were factors that were positively associated with social support. In contrast, poor/very poor perceived sufficiency of income and polypharmacy use were negatively associated with social support. Although studies of factors associated with perceived social support in older people with cancer are rare in the literature, some have observed results indicating similar relationships. ${ }^{6,20}$

A study conducted in Turkey with 364 individuals with cancer also used linear regression and found an association between social support score, better perceived income, and not living alone. It should be pointed out, however, that that study used a multidimensional perceived social support scale and that the sample was not made up exclusively of older people (mean age of participants was 53.6 years). In addition to similar associations, these authors observed higher social support scores among individuals with higher educational level, better functionality, and no comorbidities..$^{20}$

Another study, conducted in the United States with 1460 older people, aimed to analyze met and unmet social support needs in older people with cancer. The study used an adapted version of the MOS social support scale and found that older people with lower family income; lower educational level; black race; higher numbers of comorbidities; a greater cancer symptom load; and those who were divorced or had never married had unmet support needs in all types of social support. ${ }^{6}$

In contrast with the result observed in the present sample, the two studies mentioned above observed better social support scores among people, without comorbidities. One possible explanation for the difference could be that the older people with comorbidities in the present study may have greater need for care and, consequently, greater availability of support to meet their needs. Considering that in Brazil the family is the main provider of care to older people and also the main source of social support, a greater need for care 
may be related to greater proximity with relatives and, as a result, greater availability of support. ${ }^{21,22}$

The importance of social support for coping with cancer can be seen in the results of a literature review conducted with the objective of assessing patterns of unmet needs in patients with cancer and providing information on factors that influence perception of these needs. It analyzed 11 articles and found that the principal factor associated with low perceived need in the psychological domain was the social support available. Individuals living in places with strong community bonds and who reported high social support levels were more likely to have their emotional and psychological needs met. ${ }^{23}$ Moreover, a study with 757 individuals with cancer in outpatients treatment suggested that better scores in the mental and physical domains of health-related quality of life indicated better perceived social support during treatment for cancer. ${ }^{24}$

Therefore, knowing the great potential of social support as a resource for coping with cancer, the strong point of this study is to contribute information on factors related to higher and lower scores for perceived support, enabling implementation of more effective care plans.

The limitations of this study include use of a convenience sample of older people receiving care at a single hospital, which prevents generalization of the results to other populations. Additionally, secondary data on the clinical characteristics of the older people with cancer were used and the social support and SCNS-SF 34 scales have not been validated with samples exclusively comprising older people.

\section{CONCLUSIONS}

The sample of older people reported high mean scores for material support; affective support; positive social interaction; and emotional/informational support. Factors positively associated with social support were: not living alone; income of one to three times the minimum wage; having a partner; rating health as good/very good; and presence of comorbidity. Factors negatively associated were: poor/very poor perceived sufficiency of income and polypharmacy use.

Determination of the characteristics of older people with cancer, their social support levels, and the factors associated with perceived support helps to guide public policies and health professionals' actions to effectively meet these people's care needs. Use of social support as a resource for coping with cancer should be encouraged and health professionals should act as facilitators of creation and/or maintenance of support networks.

\section{CONFLICTS OF INTEREST}

The authors declare they have no conflict of interests.

\section{FUNDING}

This work was supported by the Fundação de Amparo à Pesquisa do Estado de Minas Gerais (FAPEMIG) (Call: 001/2018 - Demanda Universal) [grant number APQ-01304-18].

\section{AUTHORS' CONTRIBUTIONS}

TRPB: concept, data curation, formal analysis, methodology, project management, supervision, visualization, writing original draft and revision. GSGP: investigation, visualization, writing - original draft and revision.JGS: investigation, visualization, writing - original draft and revision. SMCLF: concept, methodology, project management, acquisition of finance, writing - original draft and revision. MCN: concept, methodology, writing - original draft and revision.

\section{REFERENCES}

1. Brasil. Ministério da Saúde. Departamento de Informática do SUS. Morbidade Hospitalar do SUS. Brasil: Ministério da Saúde. Available from: https://datasus.saude.gov.br/acesso-ainformacao/morbidade-hospitalar-do-sus-sih-sus/. Accessed in Jul 22, 2020.

2. Hurria A, Wildes T, Blair SL, Browner IS, Cohen H, deShazo M, et al. Senior Adult Oncology, Version 2.2014. Journal of the National Comprehensive Cancer Network J Natl Compr Canc Netw. 2014;12(1):82-126. https://doi.org/10.6004/jnccn.2014.0009

3. Draeger DL, Sievert KD, Hakenberg OW. Analysis of psychosocial stress factors in patients with renal cancer. Ther Adv Urol. 2018;10(6):17582. https://doi.org/10.1177/1756287218754766
4. Kadambi S, Soto-Perez-de-Celis E, Garg T, Loh KP, Krok-Schoend $J$, Battisti NML, et al. Social support for older adults with cancer: Young International Society of Geriatric Oncology review paper. J Geriatr Oncol. 2020;11(2):217-24. https://doi.org/10.1016/j. jgo.2019.09.005

5. Gottlieb BH, Bergen AE. Social support concepts and measures. J Psychosom Res. 2010;69(5):511-20. https://doi.org/10.1016/j. jpsychores.2009.10.001

6. Williams GR, Pisu M, Rocque GB, Williams CP, Taylor RA, Kvale $E A$, et al. Unmet social support needs among older adults with cancer. Cancer. 2019;125(3):473-81. https://doi.org/10.1002/ cncr.31809 
7. Applebaum AJ, Stein EM, Lord-Bessen J, Pessin H, Rosenfeld B, Breitbart W. Optimism, social support, and mental health outcomes in patients with advanced cancer. Psychooncology. 2014:23(3):299306. https://doi.org/10.1002/pon.3418

8. Sherbourne CD, Stewart AL. The Mos Social Support Survey. Soc Sic Med. 1991;32(6):705-714. https://doi.org/10.1016/02779536(91)90150-b

9. Griep RH, Chor D, Faerstein E, Werneck GL, Lopes CS. Validade de constructo de escala de apoio social do Medical Outcomes Study adaptada para o português no Estudo Pró-Saúde. Cad Saúde Pública. 2005;21(3):703-14. https://doi.org/10.1590/S0102$311 \times 2005000300004$

10. Zanini DS, Peixoto EM, Nakano TC. Escala de apoio social (MOS-SSS): proposta de normatização com referência nos itens. Temas Psicol. 2018;26(1):387-99. http://doi.org/10.9788/ TP2018.1-15Pt

11. Vieira HDW. Validade de Constructo do Supportive care needs surveyshort form 34 (SCNS-SF34) para a avaliação das necessidades de cuidados em pacientes oncológicos atendidos em Manaus [tese]. São Paulo: Universidade de São Paulo; 2017.

12. Leite GC. Tradução e adaptação cultural do instrumento Supportive Care Needs Survey Short Form - 34 [dissertação]. São Paulo: Fundação Antônio Prudente; 2014.

13. Pacagnella ABB, Santana EDB, Gome MM, Fattori A, Guariento ME. Sociodemographic profile of elderly patients with cancer in a tertiary care service of SUS. Geriatr Gerontol Aging. 2014;8(1):27-31.

14. Santos EGA, Souza JC, Santos ALS, Santos MIPO, Oliveira TNC. Perfil clínico-epidemiológico de idosos submetidos à quimioterapia antineoplásica atendidos em um hospital de referência oncológica do estado do Pará, Brasil. Rev Pan-Amaz Saude. 2017;8(2):45-54. http://doi.org/10.5123/ S2176-62232017000200006

15. Guerra MR, Gallo CVM, Mendonça GAS. Risco de câncer no Brasil: tendências e estudos epidemiológicos mais recentes. Rev Bras Cancerologia. 2005;51(3):227-34.
16. Barros MBA, Francisco PMSB, Zanchetta LM, César CLG. Tendências das desigualdades sociais e demográficas na prevalência de doenças crônicas no Brasil, PNAD: 2003-2008. Ciênc Saúde Coletiva. 2011;16(9):3755-68. https://doi.org/10.1590/S141381232011001000012

17. Kolankiewicz ACB, Souza MM, Magnago TSBS, Domenico EBL Apoio social percebido por pacientes oncológicos e sua relação com as características sociodemográficas. Rev Gaúcha Enferm. 2014;35(1):31-8. https://doi.org/10.1590/1983-1447.2014.01.42491

18. Ozbayir T, Gok F, Arican S, Koze BS, Uslu Y. Influence of demographıc factors on perceivedsocial support among adult cancer patients in Turkey. Niger J Clin Pract. 2019;22(8):1147-56. https://doi. org/10.4103/njcp.njcp_372_17

19. Rodrigues J, Ferreira N, Caliri MH. Caracterização do apoio social percebido pela família do doente adulto com câncer. Medicina (Ribeirão Preto). 2013;46(3):289-96. https://doi.org/10.11606/ issn.2176-7262.v46i3p289-296

20. Yilmaz MS, Piyal B, Akdur R. Social support and quality of life in a group of cancer patients (Ankara, Turkey). Turk J Med Sci. 2017;47(3):732-37. https://doi.org/10.3906/sag-1508-42

21. Brito TRP, Nunes DP, Duarte YAO, Lebrão ML. Social network and older people's functionality: Health, Well-being, and Aging (SABE) study evidences. Rev Bras Epidemiol. 2018;21(Supl. 2):e180003. https://doi.org/10.1590/1980-549720180003.supl.2

22. Nunes DP, Brito TRP, Duarte YAO, Lebrão ML. Cuidadores de idosos e tensão excessiva associada ao cuidado: evidências do Estudo SABE. Rev Bras Epidemiol. 2018;21(Supl. 2):e180020. http://doi org/10.1590/1980-549720180020.supl.2

23. Okediji PT, Salako O, Fatiregun OO. Pattern and Predictors of Unmet Supportive Care Needs in Cancer Patients. Cureus. 2017;9(5):e1234. http://doi.org/10.7759/cureus.1234

24. Costa-Requena G, Ballester Arnal R, Gil F. The influence of coping response and health-related quality of life on perceived social support during cancer treatment. Palliat Support Care. 2015;13(3):683-9. http://doi.org/10.1017/S1478951514000418 